\title{
BRECHT: UMA ABORDAGEM PEDAGÓGICA NO CENÁRIO CONTEMPORÂNEO DO ENSINO- APRENDIZAGEM
}

\section{BRECHT: A PEDAGOGICAL APPROACH ON THE CONTEPORARY SCENARIO OF TEACHING-LEARNING}

\author{
Ricardo Vinícius de Carvalho Delgado \\ Graduando em Teatro - Universidade Federal do Maranhão
}

RESUMO

Bertolt Brecht, em meados do século XX, escreve sua teoria do teatro épico, uma nova forma baseada na dialética palco-plateia, e na negação do efeito ilusório do teatro dramático. Seu teatro épico tinha como objetivo apresentar à plateia uma crítica da sociedade da época, baseada em mostrar o funcionamento do teatro, gerando uma visão esclarecedora da sociedade da época. Brecht nos deixou formas de ensinar, que, no cenário atual, se encaixam muito bem. Seu teatro épico e peça didática aparecem como ótimas alternativas de ensino na pedagogia do teatro, esclarecedoras tanto para plateias como para estudantes de licenciatura em teatro, do ensino médio e fundamental e atores, usando do diálogo, da crítica e do incentivo ao pensamento crítico.

Palavras-chave: Brecht, teatro épico, peça didática, pedagogia do teatro.

\begin{abstract}
Bertolt Brecht, in the middle of the twentieth century, writes the theory of epic theater, a new form based on the stage-audience dialectics, and the denial of the illusory effect of dramatic theater. His epic theater aimed to present to the audience a critique of the society of the time, based on showing the operation of the theater, creating an insightful view of the society of the time. Brecht left us ways to teach, which, in the current scenario, fit very well. His epic theater and learning play appear as great teaching alternatives in theater pedagogy, enlightening both audiences and undergraduates in theater, middle and high
\end{abstract}


school, and actors, using dialogue, criticism and encouragement of critical thinking.

Keywords: Brecht, epic theater, learning play, theater pedagogy.

\section{Introdução}

Bertolt Brecht, em 1954, apresentou pela primeira vez a peça considerada por muitos a sua mais importante: Mãe Coragem e Seus Filhos. A peça, por sua vez, apresenta uma mulher que é sustentada pela guerra (uma vendedora de armas) e que sustenta seus filhos da mesma maneira. Porém, ela vê a guerra lhe tirando cada um dos seus filhos, num sistema de autodestruição. Dessa forma, Brecht apresenta uma crítica à máquina de guerra, que gera energia para o capitalismo, e acaba destruindo aqueles que funcionam como meio, sejam vendedores ou consumidores.

Tanto nessa como nas suas outras peças, Brecht tenta passar para o espectador uma ideia, um ensinamento, que resultava de uma reflexão sobre a sociedade da época, seja sobre as consequências do capitalismo para a sociedade, ou como a guerra afetava o cidadão. A intenção pedagógica aparece ainda mais nas chamadas peças didáticas, ou learning play.

Porém, uma das suas intenções pedagógicas não era apenas para com a sociedade, mas também com a estrutura do teatro dramático da época. Brecht pretendia mostrar ao espectador o que havia por trás do método ilusionista, e assim ensiná-lo a entender como o próprio teatro funcionava.

Na pedagogia do teatro, a peça didática de Brecht aparece como um dos vários métodos de ensino do teatro. Porém, como a pedagogia brechtiana pode influenciar o processo de ensino-aprendizagem nos tempos atuais? Haveria espaço para o épico e o didático no meio da atualidade?

\section{A Pedagogia Brechtiana: Épico e Dramático}

A forma dramática do teatro, ainda usada hoje, foi executada plenamente desde o surgimento do teatro ocidental, na Grécia Antiga, até o começo do século $X X$, com Constantin Stanislávski e outros. Esta forma prioriza um envolvimento da plateia com o espetáculo, proporcionando emoções, 
vivências, identificação pessoal com os personagens, entre outros aspectos. Em uma peça totalmente dramática, sem elementos de epicização, o espectador não é intimado pessoalmente a fazer uma reflexão. Tal reflexão pode acontecer, proposta pelo enredo, mas nunca da mesma forma que o teatro épico proporciona.

A forma épica aparece não em oposição ao teatro dramático, mas como uma adequação do teatro à situação contemporânea do século $X X$. Walter Benjamin (1987) resume o novo teatro, e como as relações palco-plateia se modificaram, assim como as relações entre o texto e 0 ator, 0 ator e 0 diretor..

Para seu público, o palco não se apresenta sob a forma de "tábuas que significam o mundo" (ou seja, como um espaço mágico), e sim como uam sala de exposição, disposta num ângulo favorável. Para seu palco, o público não é mais uma gregado de cobaias hipnotizadas, e sim uma assembleia de pessoas interessadas, cujas exigências ele precisa satisfazer. Para seu texto, a representação não significa mais uma interpretação virtuosística, e sim um controle rigoroso. Para sua representação, o texto não é mais fundamento, e sim roteiro de trabalho, no qual se registram as reformulações necessárias. Para seus atores, o diretor não transmite mais instruções visando a obtenção de feitos, e sim teses em função das quais eles têm que tomar uma posição. Para seu diretor, o ator não é mais um artista mímico, que incorpora um papel, e sim um funcionário, que precisa inventá-lo.

Assim, o teatro épico de Brecht usa de mecanismos para desconstruir o teatro dramático, mostrando ao espectador, que antes ia ao teatro para ser iludido, como funcionavam os próprios mecanismos do teatro. Para Desgranges (2006), "Brecht contrapunha-se ao ilusionismo do teatro dramático e defendia uma cena que se assumisse enquanto arte, deixando a mostra suas causas e efeitos" . A intenção de mostrar, ou ensinar o espectador sobre o funcionamento do teatro aparece como o primeiro ponto importante da pedagogia brechtiana. Desgranges (2006) fala ainda mais. Para ele, a pedagogia do espectador funciona como uma alfabetização na linguagem teatral. O espectador não seria mais um ser hipnotizado pelo teatro, mas um interlocutor deste, que dialogaria, pensaria, e criticaria.

O teatro épico brechtiano se estruturava como uma pedagogia do espectador, tendo em vista que este poderia fruir mais prontamente 0 
espetáculo à medida que conhecesse melhor o aparato, constituinte de uma encenação. Seu foco estava centrado na ampliação do acesso lingüístico deste espectador, que, familiarizado com os elementos da linguagem cênica, se encontraria em condições de efetivar uma leitura própria e apurada do discurso teatral.

O segundo ponto importante da pedagogia brechtiana está na forma em que o teatro épico, ao mostrar o teatro acontecer, gera uma crítica sociopolítica à sociedade vigente. Tal crítica política é passada ao público devido ao diálogo, à argumentação palco-plateia que acontece durante o espetáculo. Desgranges (2006), novamente, usa uma cena de A Vida de Galileu que mostra o aparato cênico da troca de figurino sendo usado como crítica.

A cena se passa entre Galileu e $O$ Pequeno Monge, personagem que, além de religioso, é também um cientista. Os dois discutem a concepção cosmogônica defendida por Galileu, que, entre outras questões, contrariava bastante o posicionamento da Igreja, posto que sua visão científica tirava a Terra do centro do universo. [...] $O$ Pequeno Monge pode parecer parece simpático às opiniões científicas de Galileu, mas, no decorrer da cena, quando o cientista religioso veste o seu hábito, sua batina, seu discurso se altera notadamente, manifestando forte contrariedade às idéias de Galileu.

Esse aspecto contido na dramaturgia brechtiana é um processo de ensino-aprendizagem. O diálogo aparece como principal ferramenta, porém, existirão outras, citadas pelo próprio Brecht, como recursos dialéticos.

Um destes, tido como bastante importante, é o chamado Verfremdung, ou V-Effekt, ou efeito de estranhamento. Koudela (2007) referese ao ator da peça didática como um jogador, e à própria peça didática como um jogo. O estranhamento pode aparecer de várias formas possíveis, como o questionamento do papel pela figura do ator, falar sobre o passado, assumir uma terceira pessoa, troca de papeis, entre outros. Deve haver um objetivo na ação: impedir a identificação do espectador com o personagem. Tal identificação acontece devido ao efeito ilusório do teatro dramático, que Brecht quer impedir que aconteça. Porém

ele não necessita, nos seus esforços por retratar determinadas pessoas e mostrar seu comportamento, renunciar totalmente ao meio da identificação. Utiliza esse meio até o ponto que qualquer pessoa 
sem talento ou ambição de interpretação o utilizaria para representar uma outra pessoa, isto é, para mostrar seu comportamento. Mostrar o comportamento de outrem cotidianamente em inúmeras ocasiões sem que essas pessoas queiram provocar nos observadores uma ilusão. (BRECHT apud KOUDELA, 2007)

Ou seja, o efeito de identificação em si não deve ser renunciado totalmente, mas apenas quando causa ilusão e/ou hipnose.

Há também o conceito de gestus social, que não é apenas um gesto, movimento, mas um conjunto de gestos direcionados a uma ou um grupo de pessoas. Funciona como atitudes que determinam o comportamento de uma pessoa. Por meio do gestus, o ator dialoga com a plateia, e a plateia é informada do contexto social no qual o personagem foi criado.

Assim, pela forma dialética do épico, é claramente viável à pedagogia brechtiana estar incluida em espaços de aprendizagem, seja a escola ou o teatro.

\section{O processo de ensino-aprendizagem e a pedagogia brechtiana}

No âmbito da pedagogia teatral, o processo de ensino-aprendizagem na contemporaneidade pode dar-se de várias formas, variando com o público atingido e o professor (não necessariamente um docente). Podemos citar as formas mais comuns, que serão meu objetivo de estudo neste artigo.

1. O processo palco-plateia, já citado no tópico acima, mas que ainda será abordado brevemente;

2. O docente em teatro e o estudante do curso de Licenciatura em Teatro

3. O docente em teatro e o estudante do curso de Formação de Atores;

4. O docente em teatro e o estudante do ensino básico, fundamental e médio.

Sobre o processo palco-plateia, já falamos como o diálogo, o aparato da quebra da ilusão e outros elementos de epicização, como a quebra da quarta parede, cenas independentes, entre outros, funcionam como instrumento didático. O espectador é tratado como é: um ser com uma bagagem de experiência, que deve ser estimulado a pensar. Nesse cenário, tanto a peça 
épica, quanto apenas elementos de epicização ou a peça didática podem ser usados. O objetivo é atingido se o espectador sair do teatro com uma nova visão, ou pelo menos, com uma inquietação. Na contemporaneidade, o teatro aparece não só como entretenimento, mas também como formador de opinião. Deve ser sempre objetivo deste apresentar ao público as conjunturas sociais sob diferentes pontos de vistas, como forma de esclarecimento.

Em um curso de licenciatura em teatro, porém, a peça didática é abordada como um método de ensino do teatro. Os estudantes estão em curso de licenciatura, ou seja, almejando uma formação para a docência. É dever dos mesmos aprender a peça didática, tendo-a como uma forma de ensinar teatro, de forma que o ensino seja diversificado e prazeroso. Como diz a professora Ingrid Koudela (2007), peça didática não é uma tradução adequada, pois "implica "doar" conteúdos através de uma relação autoritária entre aquele que "detém" o conhecimento e aquele que é "ignorante. A peça didática de Brecht propõe o exercício de uma didática não depositária". Acima de tudo, Brecht considera que a plateia da peça didática não é uma "tábula rasa", mas sim um ser conhecedor, que aprendeu até certo ponto e está disposto a aprender mais, trocando experiências com o professor, que também aprende.

Porém, para Marcelo Gianini (2013)

Os jovens estudantes desses cursos não conhecem necessariamente a matéria na qual se tornarão docentes. A maioria desses licenciandos inicia seus estudos superiores com parcos conhecimentos teatrais. Conhecimentos estes advindos de rápidas experiências em oficinas teatrais e com grupos amadores e estudantis, ou mesmo somente como espectadores. Isto quando a ausência destas experiências é ainda maior, limitando-se a ideias e (pré)conceitos sobre o teatro vindos de outras linguagens midiáticas como a televisão e o cinema. [...] Desta forma, é necessário também alfabetizar os futuros alfabetizadores.

O termo alfabetizar, empregado por ele, leva em consideração que o teatro é uma linguagem, ou seja, de acordo com o Ministério da Educação (MEC), executa a função de enviar uma mensagem em código. Ou seja, um professor de teatro que não conhece o próprio teatro não saberá executar seu ofício de forma adequada. 
Segundo Gianini, porém, a solução pra isso está na peça didática. $O$ estudante que não possui nenhum conhecimento de teatro teria a chance de aprendê-lo, ao mesmo tempo em que o vê acontecer, em um processo metalinguístico bastante enriquecedor, para ambas partes. $O$ docente-artista aparece como uma figura importante, pois para uma docência eficiente, devese adquirir experiência. Como ele diz:

Nestes processos, professor e alunos se tornam parceiros de jogo, na expressão de Ingrid Koudela, estabelecendo relações baseadas na igualdade de fala, escuta e reflexão. Se o mestre do aluno é o professor, o mestre do professor é o aluno. Quando o professor deixa e aprender com o aluno, cessa a relação de aprendizagem.

Ainda no âmbito profissional, existem os outros dois cenários possíveis: alunos do curso de formação de atores e alunos de primeiro e segundo grau. A peça didática também aparece como um bom meio de ensino para alunos do ensino médio, que estão desenvolvendo seu pensamento crítico e senso político-social. Tal peça não precisa abordar apenas assuntos puramente teatrais: seria interdisciplinar, abordando história, filosofia, sociologia, geopolítica, entre outras disciplinas do currículo. A peça didática não precisa busca palcos alternativos, onde haja uma plateia disposta a interagir. Em uma escola, a interação é quase inevitável, e ao mesmo tempo, bastante enriquecedora. É puramente dialético, como citam Koudela e Santana (2005).

\begin{abstract}
Através da teoria da Peça Didática, Brecht busca uma solução reintegradora para a sociedade e para o impasse da alienação artística. Na Peça Didática, a realização do espetáculo fica condicionada à intervenção ativa do receptor na obra de arte no Kollektiver Kunstakt (ato artístico coletivo). [...] A Peça Didática ensina quando nela atuamos. Em princípio não há necessidade de platéia, embora ela possa ser utilizada. [...] Ao escrever a Peça Didática, Brecht abdica da autoria, na medida em que concebeu exercícios de dialética, nos quais o texto é experimentado cenicamente, visando à participação do leitor como ator e co-autor do texto.
\end{abstract}

Cita também Gianini (2013), que, na peça didádica, "a dramaturgia do autor abre espaço para a forma como ela será colocada na cena. O que se fala não é mais importante do que a forma como esta fala se mostra ao público." Depende do docente colocar na cena, de forma precisa, o que for necessário mostrar aos estudantes. 
O mesmo acontece em um curso de formação de atores, o uso da pedagogia brechtiana seria extremamente metalinguístico. Na licenciatura, a peça ainda pode abordar assuntos como didática teórica, metodologias, entre outros; Mas na formação de atores, há espaço apenas para assuntos de âmbito da interpretação e atuação. Talvez, para esses cursos, a peça didática não seja a melhor forma de ensino do teatro a ser usada, mas mesmo ao usar-se os jogos teatrais ou outra técnica, a dialética aparece presente. Um ator não precisa ser treinado para a técnica brechtiana, mas deve conhecê-la.

\section{Conclusão}

A pedagogia brechtiana está baseada na dialética: o palco deve dialogar com a plateia, e esta, deve ser provocada, inquietada, e responder o palco. Na conjuntura político-social atual, o teatro épico aparece novamente como esclarecedor, desalienador. Porém, isso não significa que não deva ser usado para ensinar. A peça didática é um instrumento viável em todos os cenários de ensino-aprendizagem acima. Para ser aplicável, é apenas necessário um diálogo entre dois grupos, um como professor e outro como estudante, mas esses papeis não são sempre fixos.

\section{Referências}

BENJAMIN, Walter. Magia e técnica, arte e política: Ensaios sobre literatura e história da cultura. Obras escolhidas, vol. 1. São Paulo: Brasiliense, 1987. 3 ed. DESGRANGES, Flávio. A Pedagogia Teatral em Brecht: O teatro épico. São Paulo: Fábrica São Paulo, 2006.

GIANINI, Marcelo. A peça didática de Brecht na formação de professores de teatro. In: Anais do Simpósio da International Brecht Society. Vol.1, 2013.

Disponível em: < http://www.ufrgs.br/ppgac/wp-content/uploads/2013/10/Ape\%C3\%A7a-did\%C3\%A1tica-de-Bertolt-Brecht-na-forma\%C3\%A7\%C3\%A3ode-professores-de-teatro.pdf> Acesso em 3 ago. 2016.

KOUDELA, Ingrid Dormien. Brecht: Um jogo de aprendizagem. São Paulo: Perspectiva, 2007.

SANTANA, Arão Paranaguá de. Abordagens metodológicas do teatro na educação. In: Ciências Humanas em Revista, v.3, n.2 São Luís: $2005 . \quad$ Disponível em: 
$<$ http://www.educadores.diaadia.pr.gov.br/arquivos/File/2010/artigos_teses/201

0/Arte/artigos/metodo_teatro.pdf> Acesso em 4 ago. 2016.

\section{Bibliografia}

BRECHT, Bertolt. Estudos sobre teatro. Rio de Janeiro: Nova Fronteira, 1978. 